\title{
Human Resource Management Leadership Succession in Multinationals: Are Japanese CEOs still more likely to be hired from within Company Ranks than US CEOs?
}

\author{
Jim Tanoos \\ Dept. of Business \& CIS, Saint Mary-of-the-Woods College \\ 012 Hulman Hall, Saint Mary-of-the-Woods, IN 47876 \\ Tel: 812-535-5189Ｅ-mail: jtanoos@ smwc.edu
}

Accepted: July 04, 2012 Published: August 29, 2012

Doi:10.5296/ijhrs.v2i3.2312 URL: http://dx.doi.org/10.5296/ijhrs.v2i3.2312

\begin{abstract}
The study of CEO human resource management has been popular because of the stakes involved in anticipating and predicting effects on corporate stock prices. Local customs affect regional organizational leadership philosophies, including societal norms common to America and Japan, which prompt management structures to be unique for each country. A prolonged slowdown in the Japanese economy starting in the early 1990s has caused scholars to debate the impact of coinciding declines in their traditional organizational management templates and its impact on current CEO hiring approaches for multinational corporations based in Japan. Today, many scholars predict that fewer Japanese CEOs will be hired from within company ranks. As such, this study reports on the proportions of CEOs that are hired from outside the multinational corporation in the US versus Japan.
\end{abstract}

Keywords: organizational leadership, leadership succession, multinational corporation, Japanese CEO, American CEO, seniority, hiring practices, societal norms, human resource management 


\section{Introduction}

Japanese and American human resource management styles are affected by cultural features unique to each society. Traditional cultural norms play a part in why incoming Japanese CEOs are more likely to have been employed previously by subsidiary or affiliate companies before ascending to their leadership role in comparison with US CEOs, who tend to come from successful leadership positions with outside companies (Sakado \& Lewin, 1999).

Various societal features unique to Japan have positively affected the management philosophy of promoting from within that has influenced Japanese organizations for generations (Kim \& Park, 1997; Schaede \& Grimes, 2003). However, falling profit margins during the prolonged Japanese economic stagnation that began in the early 1990s led to a gradual abandonment of some of these cultural traditions, especially in globally competitive multinational corporations (Ornatowski, 1998; Watanabe, 2000). As such, many have predicted the end of the conventional Japanese human resource practice of making "safe" hires from within the ranks of the company and the start of hiring CEOs from successful outside firms (Ballon, 2002; Kono \& Clegg, 2001).

Although Japanese companies have shifted significantly away from traditional management structures in which a defined organizational hierarchy affects promotions, the rates of change have been slow. By 2006, Pudelko (2006) reported that "promotion and compensation practices in Japanese companies are [still] significantly more seniority oriented than in American" organizations (p. 248). As such, this study will analyze the proportion of Japanese multinational CEOs who currently originate from within the company as compared to their fellow American multinational CEOs.

\section{Background}

The field of organizational leadership succession has been a noteworthy scholarly pursuit due to the vast stakes involved in profit speculation by market participants (Friedman, 2011). The study of leadership succession, especially among high-performing multinationals, has increased because of the high stakes involved in picking winners and losers in the stock market. However, there is no exact science to anticipating stock prices, and Schloetzer et al. (2012) surmised that "anticipating a change in CEO and understanding the succession process can often be a challenge for market participants" (p. 2).

Organizational succession studies in the US have tended to focus on shareholder value effects, Human Resource Management (HRM) policies, and/or family/apprentice succession strategies (Fredrickson, Hambrick, \& Baumrin, 1988; Schloetzer, Tonello, \& Aguilar, 2012). In Japan, leadership succession studies have tended to be an outgrowth of the cultural emphasis on maintenance of harmony and collective organizational cohesiveness.

Studies on general Japanese management practices were a central focus of literature in the 1980s when the Japanese economy was achieving massive financial success and gaining prestige after entering the world marketplace. Some predicted that the Japanese system of management would be adopted by other cultures because of the success of the Japanese economy through the 1980s. For example, many US management experts concluded that 
American companies would adopt the Japanese model of lifetime employment and seniority-based promotions (Neary, 1996; Pudelko, 2006). Scholarly interest in Japanese organizations peaked in the early 1990s with the publication of "The Knowledge-Creating Company: How Japanese Companies Create the Dynamics of Innovation”, a popular all-encompassing book detailing the secrets of how Japanese multinationals became so successful (Numagami, Karube, \& Kato, 2010). However, since the stagnation of the Japanese market starting in the early 1990s, emphasis on Japanese organizational leadership has received less attention (Numagami et al., 2010). Now, many predict that Japanese leadership succession will more likely resemble American management approaches.

In the past, few Japanese companies hired CEOs from outside the company (Debroux, 2003; Schaede \& Grimes, 2003). However, specific reports of outside versus inside CEO hiring rates have not been as prevalent in Japan as in the US. US CEO hires from outside the company have been on the rise for decades, increasing from $12.7 \%$ in the early 1980 s to $35 \%$ in 2005 (Murphy \& Zabojnik, 2007). Another report found that 25\% of US S\&P 1500 companies between 2007 and 2009 had CEOs from outside the firm (Barrett, 2012).

Globally, companies have been hiring more CEOs with no prior employment with the company. In a study of the world's 2,500 largest companies for 2009, 2010, and 2011, 22\% of CEOs came from outside the company in each of those years (Booz \& Co., 2012). Favaro, Karlsson, and Neilson (2011) assessed 291 succession events for the world's top public companies in 2010 and found that outsiders were hired as CEO 19\% of the time. Schloetzer, Tonello, and Aguilar (2012) reported that of all S\&P 500 companies in 2011, $19.2 \%$ of successions involved the appointment of a CEO from outside the organization. A rare study of Japanese insider versus outsider CEO hires was done by Lucier et al. (2003), who reported that the percentage of outsider CEOs in Japan was 14\% in 1995 but shrank to 4\% in 2003, versus 28\% in North America and 44\% in Europe in 2003.

Many attribute the extremely low proportion of Japanese CEO hires from outside the company to unique societal traditions. Japanese organizational culture has been distinctive for so long because it has tended to follow cultural values exclusive to Japan (Bebenroth \& Kanai, 2010). For instance, the kohai-sempai system stems from the emphasis on collective harmony and Confucian values in Japanese society. The sempai-kohai system has been a strong standard to which Japanese communities adhere and still thrives as a model by which Japanese organizations abide. Sempai means older or senior, and kohai means next, or the person who follows (Kaisha, 1999). The kohai-sempai relationship in Japan necessitates that the younger person owes respect and loyalty to the older and that the older person owes guidance and advice to the younger person, who will learn and then replace the senior worker (Pudelko, 2006). Thus, in many Japanese organizations the prior CEO groomed the new $\mathrm{CEO}$ as the apprentice. The CEO agreed to this mentoring role and graciously made the effort to groom the apprentice to keep with tradition and leave a positive organizational impression as a respected outgoing leader.

Another cultural difference between the US and Japan that affects organizational philosophy is the emphasis on individualism versus collectivism, or the values placed on in-groups versus out-groups (Hofstede, 1980; Schaede \& Grimes, 2003). The Japanese, who have labeled this phenomenon uchi-soto, distinguish between the in-group and out-group 
and see their employer as an important in-group to be held in high regard, almost like their own family. On the other hand, American culture tends to emphasize traits conducive to out-groups, such as individuality and personal ambition. Since Japanese view co-workers as a key in-group, many promotions are made with the in-group in mind (Haghirian, 2000; Neary, 1996), resulting in a tendency to hire CEOs from within company ranks that reflects the emphasis on collectivism in societal norms.

An additional societal principle that affects Japanese leadership succession is the adherence to ringisho. This is a management philosophy in which communication is shared throughout the organization and an idea originates in consensus at the bottom and travels up the chain of command. Comparatively, the US philosophy of "top-down" management contains strict lines of authority starting with the CEO (DeFrank et al., 1985). Positive interpersonal relationships, rapport, and harmony are valued in Japanese organizations and are at the heart of ringisho. By contrast, autonomy and independence are valued in the US (Kobayashi \& Burke, 1976; Neary, 1996). Consensus-building is a crucial ingredient in this process which is seen as critical for a successful Japanese organization (Numagami et al., 2010). As a result, Japanese companies are more likely to have long-tenured employees such as functional managers and insiders who are closely aligned with the company on their Board of Directors (Board). These members do not necessarily represent shareholder interests, unlike independent outsider Board members common among American companies (Clark, 1979; Sakano \& Lewin, 1999). Fostering harmonious dialogue from each level upward advances consistency in leadership and organizational culture for Japanese multinationals.

The nenko, or senior wage system (SWS) model, is another traditional Japanese organizational model that permeates human resource management customs. The nenko model is the Japanese arrangement of promoting workers in the order of their proximity to retirement (Beiske, 2007). The seniority system stayed strong in part because it was believed that it helped spur loyalty (Kim \& Park, 1997) and is considered one of the three pillars of Japanese HR management, along with life-long employment and company unions (Debroux, 2003; Pudelko, 2006). The seniority system encourages full compliance of immediate subordinates from managers, since the managers will not be fearful of a consequence where the subordinate will be a competitor for advancement. This type of communication tends to be conducive to the Japanese participative and consensual style of bottom-up decision making (Pascale, 1978; Schaede \& Grimes, 2003). The nenko model, however, is a Japanese organizational trait that is utilized less now than it was in the early 1990s before the country's economic stagnation.

In the mid-1990s, the SWS started to be gradually replaced by an annual pay system in which the worker is paid at the end of the year based on merit (Kanai, 2009; Kim \& Park, 1997; Pudelko, 2006). This occurred in part because Japanese multinationals were losing market share and were depicted as being less innovative and creative. Ornatowski (1998) reported that by 1996, only $10 \%$ of large Tokyo Stock Exchange-listed companies still supported the traditional Japanese seniority-based pay and promotion system. However, these companies did want to continue lifetime employment, defined by the Japanese Ministry of Labor as the "practice of companies to hire their core employees primarily from new 
graduates-plan their continual training-until age 55 or 60 -and not discharge them" (Ornatowski, 1998, p. 3). By the end of the 1990s, there was a decreased emphasis on the Japanese SWS in CEO advancement for Japanese multinationals (Ballon, 2002; Kono \& Clegg, 2001; Ornatowski, 1998; Watanabe, 2000).

Japanese traditions affecting organizational succession also are revealed in trends in more formal succession hierarchy management practices. This is depicted in the long-established management plan wherein a) the CEO is instructed to groom the apprentice in order to eventually take the place of the CEO, b), the public is informed of the plan, and c) the outgoing CEO eventually takes the Chair position in order to guide the new CEO, which is referred to as the "apprentice model" of succession. This type of transparent, orderly succession is on the decline. $95 \%$ of Japanese organizations utilized the apprentice model in 2000, but this decreased to $82 \%$ in 2008 (Booz \& Co., 2008). By 2011, only 63\% of Japanese organizations used the apprentice model, though this is still higher than $37 \%$ in North America and just $17 \%$ in Europe (Booz \& Co., 2012).

American organizational advancement practices also have been influenced by unique cultural norms that have translated into higher numbers of CEOs being hired from outside of company ranks as compared to Japanese CEOs.

The American societal emphasis on individualistic qualities leads to differences in leadership succession practices as compared to Japan. Pudelko (2006) found in a study of multiple HRM cultures that Japanese HR managers rated lowest on a series of individualistic management functions including top-down decision making, selection based on performance, and finding the best candidate from outside the company versus inside the company. Japanese managerial scores rated as most different than American scores.

American CEOs are more likely to leave a company due to favorable organizational results because of the traditional societal emphasis on personal career advancement. In addition, DeFrank et al. (1985) found that American CEOs are more likely to exhibit Type A behaviors, which are conducive to ambition and individualism, as compared to Japanese CEOs, who display socially oriented or paternalistic and family-oriented approaches of management. This tendency of American leaders to switch jobs for more prestigious positions elsewhere is the result of an individualistic mindset, rather than the collective, team-focused worldview that informs Japanese organizational practices. This approach also has tended to be reflected in higher salaries. In fact, a recent study based on a US investment banking division found that external hires made $18 \%$ more than internal employees in similar position (Bidwell, 2011). Americans are more likely to see their place of work as a pathway to money and power (Clark, 1979).

Another dynamic contributing to American leadership succession differences is the emphasis on stock returns. US CEO organizational strategy is more short term-based and is much more affected by stock returns than Japan organizations (DeFrank et al., 1985). Sakano and Lewin (1999) found that the stock market in the US tends to predict CEO succession.

An additional societal factor contributing to American CEO hiring practices is the makeup of the company Board. In America, the Board's main function is to act on behalf of 
shareholders, whereas Japanese Boards are focused on maintaining harmony between the company, the Board, and society and are less likely to act when company stock prices dip (Clark 1979; Sakano \& Lewin, 1999). In the US, Boards tend to be more likely and able to push for a CEO change and even a complete culture change when profitability begins to lag, often resulting in a hire from outside the company (Crain et al., 1977). Hiring an ambitious outsider is a popular method of overhauling an organization, and the unique makeup and direction of a US Board which answers to shareholders, not the company, often results in CEOs coming from outside the firm.

Historically, the greatest increases in American organizational performance occur when the new CEO is an outsider rather than an insider (Brady \& Helmich 1984; Chung et al. 1987; Helmich \& Brown, 1972; Wiersema, 1992). However, more recent research in this area has reported different results. One study reported that between 2009 and 2011, CEOs that were promoted from within company ranks brought a 4.4\% annual shareholder return above local indices as compared to just $0.5 \%$ from outsiders (Booz \& Co., 2012). Favaro, Karlsson, and Neilson (2011) assessed 291 succession events in 2010 from the world's top public companies and found that insider CEOs leaving office generated total shareholder returns on a basis of $4.6 \%$ as compared with just $0.1 \%$ for outsider CEOs. Booz and Company (2012) noted the difference between higher recent stock returns from company insider CEOs versus outsider CEO hires.

The rate of outsiders appointed as CEO is demonstrably higher than it was before the recession began, which suggests that companies are seeking leadership experience from outside their industries and markets. However, our study finds that insider CEOs continue to perform better, bringing higher shareholder returns and serving longer tenures. These countervailing trends -- better-performing insiders and increasing numbers of outsiders -- are currently at a crossroads and should be a consideration for any Board thinking about making a change. (Booz \& Co., 2012, p. 2)

Conflicting reports of earnings from outsider versus insider CEO hires have prompted scholars to predict that more favorable profits from CEO hires from within company ranks will translate into US companies starting to hire insider CEOs at percentages closer to Japanese rates.

Other factors affect the different proportions of outsider versus insider CEO hires in the US. For instance an organization's earnings might predict rates of insider versus outsider CEO hires. Past studies have reported that larger multinationals are more likely to use the apprentice model and promote an insider as CEO while lower performing companies are more likely to choose a CEO from outside company ranks (Schloetzer, Tonello, \& Aguilar, 2012). Schloetzer, Tonello, \& Aguilar (2012) found that multinationals have been more likely to appoint a CEO previously working within company ranks for a long time and stated that "better-performing companies appointed seasoned executives--those with tenure in the company exceeding 20 years--far more frequently than their poor-performing counterparts" ( $\mathrm{p}$. 3). To adequately compare CEO leadership succession within like organizations from Japan and the US, it is useful to examine companies of comparable sizes.

Understanding different types of Japanese versus American CEO succession- and predicting the results- is important for market participants because correctly anticipating the 
effects of these changes can be lucrative. Scholars have debated the current effect on traditional societal attributes specific to Japan and the US on management structure and stock returns. With the world economy constantly integrating and cultural dynamics evolving, and with the decline in Japanese organizational adherence to traditional societal norms as well as outsider American CEO hires performing better in the stock market during the ongoing recession, scholars have speculated that Japanese and American leadership succession practices will converge on a new global norm. With this in mind, the goal of this study is to evaluate proportions of insider versus outsider hires from current Japanese and American multinational companies.

\section{Methods}

Assessing leadership succession of comparable American versus Japanese multinational companies would necessitate the use of an all-inclusive, reputable, non-biased, comprehensive list. As such, The Fortune Global 500 was utilized. This list is the annual ranking of companies in order of revenues published by CNN, Fortune Magazine, and Money Magazine. The top 50 revenue-earning organizations in 2011 from Japan and the United States were taken as the sample set.

In order to assess the similarity of the revenues, the 2011 ratio of earnings for each group of 50 companies was compared. The ratio of revenues for the 50 multinationals in the sample set of US/Japan companies was 1.75 to 1 . Although this ratio is not precisely 1.0 as this study would ideally envision in order to compare like companies, these multinationals are alike in that they are viewed similarly by their societies as the most successful models of organizational success and thus provide useful models as the most successful domestic companies in which each culture determined its management practices.

Each sample of multinationals was thoroughly investigated in order to assess the past job roles filled by each current CEO as of June 2012. Through a variety of sources including newspaper articles, company websites, and other means, information on the sample set was accumulated. In many cases, information regarding the prior work experience and past company positions held was included for the Japanese CEO on their organizational websites.

\section{Results}

In Japan, 49 of the 50 multinational CEOs held prior employment with an affiliate, subsidiary, or lower level company position with the organization before eventually becoming CEO. Only $2 \%$ of the companies hired an outsider. In almost all cases, the CEO had worked his way up the company hierarchy for many years and often had been the head of an affiliate or subsidiary company at some prior point. The lone exception was for Japan Post Holdings, whose CEO Jiro Saito previously worked as the CEO of the Tokyo Financial Exchange.

Although decreasing proportions of Japanese CEO hires from outside the company have been reported, this $2 \%$ statistic was even lower than in Lucier et al.'s (2003) report which found that only $4 \%$ of Japanese CEO hires come from outside the company.

In the United States, the CEO of 8 of the 49 companies (one company had an interim CEO and was not included in the sample), or $16.3 \%$, were hired from an independent outside 
company. These statistics compare to $19 \%$ and $19.2 \%$ of outsider hire CEOs from studies in 2010 and 2011. The figure below depicts these statistics. The downward trend of hiring from the outside falls in line with recent, non-traditional reports depicting higher stock returns from insider CEO hires.

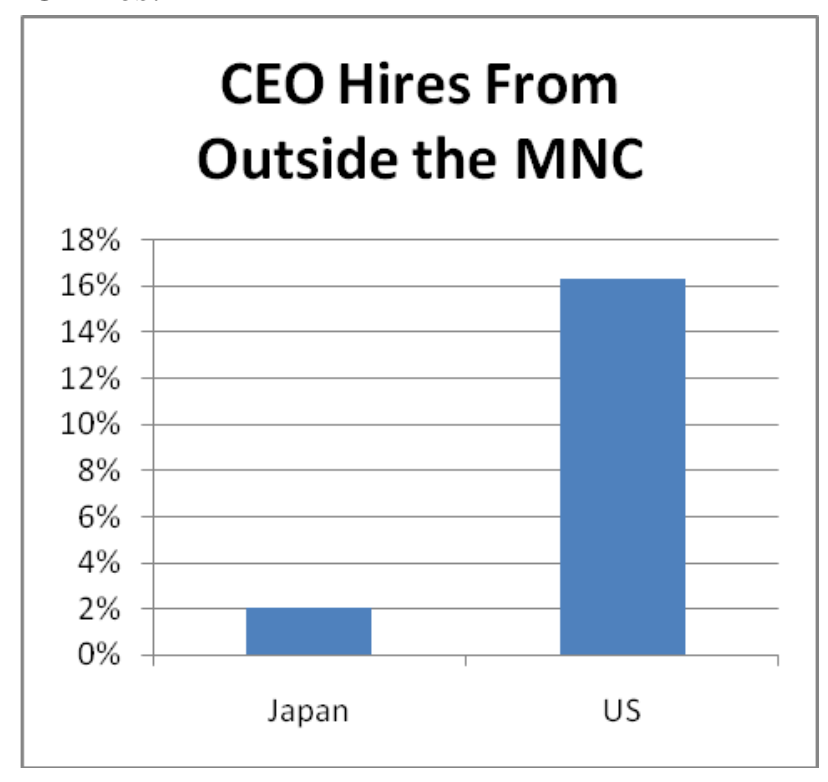

Figure 1. Percentage of CEO Hires coming from outside of the MNC

The percentage of CEOs from the Top 50 Japanese Multinational Corporations hired their CEO from outside of the organization in $2 \%$ of the instances, whereas the percentage of CEOs from the Top 50 American Multinational Corporations hired their CEO from outside of the organization in $16.3 \%$ of the instances.

These statistics suggest that US companies now might be less likely to hire an outsider than the global norm of 22\% from 2009, 2010, and 2011 reported by Booz and Co. (2012). Another conjecture might be that American companies are following the trend of hiring an insider due to better recent stock returns, also outlined in the Booz and Co. (2012) recommendation. However, Booz and Co.'s (2012) coinciding suggestion that American companies still hire more outsider CEOs than the average global rate is not seen as having validity based on our sample set.

It is apparent that although both US and Japanese high-performing multinational CEOs are likely to originate from the lower ranks of the company, it is still more likely in the US that the company would hire from outside, even though this was lower than the percentage of outside hires in other reports.

\section{Future Studies}

Future studies might assess a larger sample size or companies in different sectors of the market to ascertain types or sizes of organizations that tend to promote from within or hire from the outside. Another inquiry is whether the formal application of the apprentice model coincides with the increasing proportions of insider CEO hires as a formal human resource management function in the US. 


\section{References}

Ballon, R. (2002). Human Resource Management and Japan. Euro Asia Journal of Management, 12, 5-20.

Barrett, A. (2012). Equilar Study: CEO Turnover: Findings from a study of CEO departures at S\&P companies between 2007 and 2009. Retrieved from http://www.equilar.com/knowledge-network/research-articles/201104-ceo-turnover.php.

Bebenroth R., \& Kanai, T. (2010). Challenges of Human Resource Management in Japan. New York, NY: Routledge Publishing.

Beiske, B. (2007). The System of Wage-Setting Japan, Germany and the US: Towards convergence? Norderstedt, Germany: Druck und Bindung.

Bidwell, M. (2011). Paying More to Get Less: Specific Skills, Matching, and the Effects of External Hiring versus Internal Promotion. Administrative Science Quarterly.

Brady, G., \& Helmich, D. (1984). Executive Succession: Toward excellence in corporate leadership. Englewood Cliffs. NJ: Prentice-Hall Publishing.

Chung, K., Lubatkin, M., Rogers, R., \& Owens, J. (1987). Do Insiders Make Better CEOs Than Outsiders? Management Executive, 1, 323-329.

Clark, R. (1979). The Japanese Company. New Haven, CT: Yale University Press.

Debroux, P. (2003). Human Resource Management in Japan: Changes and uncertainties. Burlington, VT: Ashgate Publishing Company.

DeFrank, R., Matteson, M., Schweiger, D., \& Ivancevich, J. (1985). The Impact of Culture on the Management Practices of American and Japanese CEOs. Organizational Dynamics, 13(4), 62-76.

Favaro K., Karlsson, P., \& Neilson, G. (May 24, 2011). CEO Succession 2010: The four types of CEOs. Retrieved from http://m.strategy-business.com/article/11207?gko=d3a9c.

Fredrickson, J., Hambrick, D., \& Baumrin, S. (1988). A Model of CEO dismissal. Academy of Management Review, 13(2), 255-270.

Friedman, S. (2011). Leadership Succession. New Brunswick, NJ: Transaction Publishers.

Haghirian, P. (2000). Understanding Japanese Management Practices. New York, NY: Business Expert Press.

Helmich, D., \& Brown, W. (September, 1972). Successor Type and Organizational Change in the Corporate Enterprise. Administrative Science Quarterly, 17, 371-381.

Hofstede, G. (1980). Culture's Consequences. Beverly Hills, CA: Sage Publishing. 
Kaisha, K. (1999). Japan: Profile of a nation. Tokyo, Japan: Kodansha International.

Kanai, A. (2009). Karoshi (Work to Death) in Japan. Journal of Business Ethics, 84, 209-216.

Kim, D., \& Park, S. (October, 1997). Changing Patterns of Pay Systems in Japan and Korea: From seniority to performance. International Journal of Employment Studies, 5(2), 117-134.

Kobayashi, M., \& Burke, W. (Summer, 1976). Organization Development in Japan. Colombia Journal of World Business, 113-122.

Kono, T., \& Clegg, S. (2001). Trends in Japanese Management. Continuing strengths, current problems and changing priorities. Houndmills, New York: Palgrave Publishing.

Lucier, C., Schuyt, R., \& Handa, J. (2003). CEO Succession 2003. The Perils of Good Governance. Booz Allem Hamilton Annual Study. Retrieved from http://www.boozallen.com/media/file/139656.pdf.

Murphy, K., \& Zabojnik, J. (2007). Managerial Capital and the Market for CEOs. Manuscript, University of Southern California.

Neary, I. (1996). Leaders and Leadership in Japan. Midsomer Norton, UK: Curzon Press, Ltd.

Nonaka, I., \& Takeuchi, H. (1995). The Knowledge-Creating Company: How Japanese Companies Create the Dynamics of Innovation. New York, NY: Oxford University Press.

Numagami, T., Karube, M., \& Kato, T. (November, 2010). Organizational Deadweight. Academy of Management, 24(4), 25-37.

Ornatowski, G. (Spring, 1998). The End of Japanese-Style Human Resource Management? Sloan Management Review, 39(3), 73-84.

Pascale, R. (March-April, 1978). Zen and the Art of Management. Harvard Business Review, 56(2), 153-162.

Pudelko, M. (2006). The Seniority Principle in Japanese Companies; A relic of the past? Asia Pacific Journal of Human Resources, 44(3), 276-294.

Sakado, T., \& Lewin, A. (September-October 1999). Impact of CEO Succession in Japanese Companies: A coevolutionary perspective. Organizational Science, 10(5), 654-671.

Schaede, U., \& Grimes, W. (2003). Japan's Managed Globalization: Adapting to the twenty-first century. Armonk, NY: M.E. Sharpe Publishing, Inc. 


\section{Macrothink

Schloetzer, J., Tonello, M., \& Aguilar, M. (April, 2012). Report Number R-1492-12-RR. CEO Succession Practices: 2012 Edition. The Conference Board. Retrieved from http://www.conference-board.org/press/pressdetail.cfm?pressid=4453.

Wiersema, M. (1992). Strategic Consequences of Executive Succession Within Diversified Firms. Journal of Management Studies, 29, 73-94. 